makes its own laws, and what Dr. Maier had to say applies primarily to the canton of Zurich. The enlightened laws of this canton forbid the marriage of the insane and mentally deficient and ordain that if such marriages are contracted in defiance of the law, they shall be dissolved. Sterilisation (that is, ligature of the genital ducts) is legal in Zurich if it is performed on medical grounds; but the judges have ruled that if the condition of the affected person is such that it is certain that he or she will produce defective offspring, then that is a sufficient medical ground for sterilisation. The insane, which in practice means persons afflicted with recurring attacks of insanity, and the obvious mental defectives, are confined in asylums; but this involves a very heavy expense to the canton, and the effort is made by nursing and rest to restore them to a better state of health and then to give them their freedom. If they are sterilised before they go out, all fear of undesirable progeny is eliminated. Sterilisation is also performed where a woman in poor circumstances, who has had a large family and is unable without grave risk to bear any more, desires it, but the written consent of the patient is required. A curious point arises in connexion with what are called borderline cases of mental defect, that is, high grade mental defectives. If, Dr. Maier states, the mental defect is accompanied by moral defect, then sterilisation is insisted on, for experience has shown that such moral defect is very prone to be inherited.

\section{The Eugenic Problem in Great Britain}

Scientific men generally, we think, will view with approval the sterilisation laws of Zurich ; if obvious mental defectives were sterilised in England, it would be a great benefit, and it would in some degree diminish the numbers of the 'social problem group', but it would not solve the great eugenic problem which confronts the country. Mental defect is not a clearly defined factor or 'gene' but a damage of infinitely graded character. In its higher grades it merges insensibly into mere foolishness and idleness. Yet it is precisely these grades which produce most offspring and hand on the defect to posterity. Until the second half of the nineteenth century, these unfortunate offspring to a large extent died out before producing children. But our social legislation has raised their survival rate and thrown the cost of their maintenance on the really fit members of the com. munity, who have in consequence restricted the numbers of their own offspring. These high grade defectives are people whom no government would dare to sterilise as a result of an examination in a mental clinic, and Dr. Maier frankly admits that this is so. A remedy for this state of affairs would be to adopt sterilisation as a penalty for bringing into the world children whom the parents are unable to support. It would be to apply compulsorily the treatment which Dr. Maier gives to poorer class women of Zurich with their consent. Public opinion in England will not easily be reconciled to this course, but if our over-population and unemployment continue, we may ultimately be driven to it.

\section{Sale of Iron Age Antiquities}

WHAT is undoubtedly the most important collection of prehistoric antiquities ever to come under the hammer is to be offered for sale at the American Art Galleries, New York, in the late autumn. The collection of some 20,000 bronze and iron objects, known as the "treasures of Carniola", is to be sold by order of the Duchess Marie Antoinette of Mecklenburg. It is her private property and was formed as the result of ten years' excavation in Carniola, about 200 miles south-east of Hallstadt, where some 1,300 tombs were opened; but it also includes material from a number of smaller sites outside Carniola. The excavations were made under an exclusive licence granted to the Duchess. As the antiquities were obtained at the very heart of the region in which the Hallstadt Iron Age civilisation developed, its importance for the archæologist is manifest. Yet until now, little has been known of it. The finds range in time from the finest period of the Hallstadt culture down to the beginning of the Roman Provincial civilisation and thus cover a most important period in the development of European peoples. Although all the objects in the collection have been photographed by the authorities of the Swiss Federal Museum in Zurich before shipment to the United States, it will be little short of a calamity that such a collection should be dispersed. Its unique interest and scientific value lie in the fact that as a whole it represents with a measure of completeness the development of culture in one area over a considerable period of time, thus illustrating important phases of transition in European prehistory. Even in the unlikely event that the collection should be purchased as a whole, its divorce from its country of origin, or at least from Europe, is to be deplored. The fate of the collection illustrates once more the danger of private ownership of antiquities which are primarily national possessions but none the less of vital interest to the whole world of archæological science.

\section{Cost of German Scientific Periodicals}

THE complaints with regard to the high cost of German scientific periodicals, which were detailed in an article by Dr. Wilfrid Bonser, librarian of the University of Birmingham, in Nature of July 1. p. 34, were embodied in a memorandum which was sent to the Börsenverein der deutschen Buchhändler on June 1. This memorandum was signed by the vice-chancellors and principals of all the universities and university colleges of Great Britain, and by the presidents of most of the scientific societies interested. An answer has now been received from the Börsenverein. This announces that an agreement has been made between the Börsenverein as representing the publishers and the Verband der deutschen Hochschulen as representing the contributors to the journals. The various demands that have been made in Germany, Great Britain and the United States are dealt with and acceded to. The maximum size and price are in future to be announced beforehand and adhered to, thus enabling librarians to budget 
in advance: the greatest concentration and discrimination will be exercised by the contributors : dissertations will be rejected as having no proper place in periodicals. It is expected in consequence "that periodicals inflated in size and price, especially in the field of medicine and natural sciences, will be cut down from 1934 onwards by at least $20 \%$ in size and price as compared with the position in 1933". The Börsenverein declares that it will regard non-observance of this agreement as "an offence against the statutory duties of its members".

\section{Thomas Young and Colour Mixtures}

For the Thomas Young Oration delivered before the Physical Society on October 6, Dr. Herbert Ives chose for his subject "Thomas Young and the Simplification of the Artist's Palette". 'The experimentally well established fact enunciated by Thomas Young that all colours may be matched by the mixture of three properly selected primaries, has been extensively used in colour photography and typographic printing. It has not, however, been heretofore successfully used in painting. The simplification indicated by the three-colour principle has been retarded in realisation largely owing to the mistaken, but widely held, belief that the primary pigment colours are red, yellow and blue. Actually the pigment primaries, which act by subtraction or absorption of light from white, should be complementary in hue to the red, green and blue, which are the primaries for mixing light by addition. Those colours are minus red (spectrum minus red) or turquoise, a minus green or crimson, a minus blue or yellow, each having wide overlapping spectral reflection bands. Pigments of these colours, of proper spectral characteristics, are capable of mixing in pairs to make red, green and blue, and all three together to make black. When mixed with white all variations of saturation and hue are obtained. The practical problem consists in procuring pigments possessing the indicated spectral reflectivities, and having satisfactory chemical properties, such as freedom from reaction with the oil or other medium, and satisfactory permanence. Due to the very great advances which have been made in the dye industry to meet recent demands for permanent colours for automobiles and outdoor signs, it is now possible to select pigments nearly enough meeting the scientific requirements to test the practicability of the principle. This has been done with success, and pictures so painted were exhibited in connexion at the meeting. The great advantage of a three-colour palette is its simplicity and freedom from ambiguity.

\section{Diet and Cancer}

Many food products of the most varied kinds have been incriminated from time to time as being causative of the supposed increase of cancer. One of these in particular is the tomato, and Bellows and Askanazy of Geneva have stated that they have produced in white rats cancer of the sarcoma type by injection of tomato juice or of a particular bacillus obtained from the tomato, and also by feeding the animals with the juice. In a recent communication in the Lancet (Sept. 23, p. 698) M. J. A. des Ligneris records attempts to confirm these observations in South Africa, with completely negative results. Others have also similarly failed, and it is mentioned that Askanazy himself in another series of experiments obtained no further positive results. It is suggested that the presence or absence of some constitutional factor in the experimental animals determines whether or no cancer develops. If this factor is present, any adequate chronic irritation, such as that produced by tomato juice, suffices to induce cancer formation.

\section{The Bureau of Mines and the U.S. Petroleum Industry}

Mr. H. C. Fowler in his paper on "Petroleum and Natural Gas Studies of the United States Bureau of Mines" (Information Circular 6737, July 1933) gives an important résumé of the work of the petroleum and natural gas division of the U.S. Bureau of Mines. The chief motive of the Bureau is to collect and correlate the best available knowledge and information regarding physical phenomena, and thereafter make analyses of the data received with the view of delineating laws and fundamental relationships having practical application to problems of economic production, transportation and manufacture of gas and oil. During recent years, with the rapid growth of the industry, innumerable complex problems have arisen and in consequence the scope of the Bureau's work has changed and enlarged materially since its inception in 1914. The technique of practical oil and gas production is now more generally known and the Bureau is, therefore, able to concentrate on studies of a fundamental nature and on problems incapable of solution by individual concerns. Technical problems now confronting the Bureau concern refining; production of gas and oil, including related problems of pipe-line transportation of natural gas ; engineering field studies; and special engineering problems, including technical research for information sought by the industry. The chief value of the Bureau's work, however, lies not in the multiplicity of problems under investigation but in the fact that all published information is definitely based on results of commercially independent experimentation and investigation. No statistics or data are published without being first subjected to rigorous scrutiny within the Bureau, and frequently such information is critically reviewed by recognised national authorities in the industry before release. Finally, the Bureau places its detailed and valuable findings without reservation at the disposal of a world-wide technical public, long since mindful of its obligation to a most efficient and learned body.

\section{Suspension of Excavation at Verulamium}

$\mathrm{A}_{\mathrm{T}}$ the close of the present season, the excavations on the prehistoric and Roman sites of Verulamium at St. Albans, it is announced, will be suspended for a period of indefinite duration. The Excavations Committee, under the supervision of which the work 